\title{
A new species and new records of Engytatus from the Hawaiian Islands (Heteroptera, Miridae)
}

\author{
Dan A. Polhemus' \\ I Department of Natural Sciences, Bishop Museum 1525 Bernice Street, Honolulu, HI 96817 USA \\ Corresponding author: Dan A. Polhemus (bugman@bishopmuseum.org)
}

Academic editor: A. Wheeler | Received 19 September 2017 | Accepted 10 October 2017 | Published 15 November 2018

http://zoobank.org/5FFD68C6-F48E-4E72-851F-44E50332DC10

Citation: Polhemus DA (2018) A new species and new records of Engytatus from the Hawaiian Islands (Heteroptera, Miridae). In: Wheeler Jr AG (Ed.) A Festschrift Recognizing Thomas J. Henry for a Lifetime of Contributions to Heteropteran Systematics. ZooKeys 796: 97-106. https://doi.org/10.3897/zookeys.796.21054

\begin{abstract}
Engytatus henryi sp. n. is described from the Waianae Mountains of Oahu. This new species feeds on Abutilon sandwicense (Malvaceae), an endangered understory plant in mesic forests. A dorsal habitus photograph and line drawings of key male genitalic structures are provided for E. henryi, accompanied by a photograph of the host plant. Cyrtopeltis kahakai Asquith is given a new generic assignment as Engytatus kahakai (Asquith) new combination, and additional locality and host-plant records are provided for four other Hawaiian endemic Engytatus species.
\end{abstract}

\section{Keywords}

Engytatus, Hawaii, new species, new records

\section{Introduction}

The genus Engytatus is represented by 28 species worldwide, and has undergone a modest insular radiation in the Hawaiian Islands, where 9 endemic species have been previously known to occur, most of them single-island endemics (Perkins 1912, Carvalho and Usinger 1960, Gagné 1968, Asquith 1992). These species occur on host-plant species in the genus Cyrtandra in the Gesneriaceae; Dubautia in the Asteraceae; Lysmachia in the Primulaceae; Phyllostegia in the Labiatae; Scaevola in the Goodeniaceae; and Sida in the Malvaceae. In the course of general Heteroptera surveys in the Waianae

Copyright Dan A. Polhemus. This is an open access article distributed under the terms of the Creative Commons Attribution License (CC BY 4.0), which permits unrestricted use, distribution, and reproduction in any medium, provided the original author and source are credited. 
Mountains of Oahu, the author discovered yet another new species in this insular assemblage, present on Abutilon sandwicense, another host plant in the Malvaceae. This new species is described below, and additional geographic and host-plant records are provided for four other native Hawaiian Engytatus species. In particular, it is shown that individual Engytatus species utilize multiple host species in the genus Cyrtandra on Oahu, and multiple species of Dubautia on Maui, indicating that species isolating mechanisms operate primarily at the host-plant genus level in Hawaiian Engytatus.

\section{Methods}

All measurements in the descriptions below are given in millimeters, and were made using a Wild M3Z dissecting microscope equipped with an ocular micrometer. High resolution dorsal habitus photographs were taken using an AutoMontage digital imaging system linked to a Leica M165-C dissecting stereomicroscope, with post-processing using Photoshop software. Line drawings of male genitalic structures were made using a camera lucida attached to a Wild M3Z dissecting microscope.

Synonymies provided under species are nomenclatural only, rather than comprehensive for all previous citations in the literature. For material collected by the author, CL numbers following localities refer to a collection locality-numbering scheme used to cross-reference photographs and other metadata to specific collecting localities.

Nomenclature for host plants follows Wagner et al. (1999). Host plant determinations were verified by consultation with botanists at the Bishop Museum, and checked against voucher specimens in the Herbarium Pacificum at that institution. In cases where the botanical names provided on original host-plant labels for the Engytatus specimens examined have now been superseded due to more refined taxonomic interpretations, the currently accepted host-plant name is provided in brackets following the name originally used on the label. Collection locality elevations originally taken with an altimeter reading in feet have also been converted to metric values in brackets.

The following abbreviations are used for specimen depositories:

BPBM Bernice P. Bishop Museum, Honolulu, Hawaii, USA.

USNM United States National Museum of Natural History, Smithsonian Institution, Washington, DC, USA.

\section{Taxonomy}

\section{Genus Engytatus Reuter, 1876}

Discussion. The Hawaiian species currently held in Engytatus were all originally described in the genus Cyrtopeltis (Perkins 1912, Carvalho and Usinger 1960, Gagné 1968), within which Engytatus was considered a subgenus by most authors, although 
Zimmerman (1948) treated it as a full genus and placed the Hawaiian species described at that time within it. Cassis (1986), in his doctoral dissertation, subsequently elevated all subgenera of Cyrtopeltis, including Engytatus, to full genus status, a taxonomic arrangement subsequently followed in the catalog of Schuh (1995), thus validating Zimmerman's previous interpretation. Asquith (1992) described yet another Hawaiian Cyrtopeltis species, but gave no subgeneric assignment, and made no comment regarding his decision to use this genus name in preference to Engytatus. In the current work, all Hawaiian species formerly assigned to Cyrtopeltis are considered to fall within the generic limits of Engytatus as it is currently interpreted. In addition to the endemic Hawaiian species, another widespread Engytatus species, E. modestus (Distant), has also been introduced to the Hawaiian Islands, where it is a pest of tomato and other agricultural crops (Tanada and Holdaway 1954).

Following a modest amount of targeted collecting and taxonomic scrutiny from 1930-1968, Hawaiian Engytatus species have been infrequently collected or discussed in the scientific literature over the past 45 years. However, more recent records for previously described species, listed below, as well as the discovery of a new species, as reported herein, indicate that these insects are still present, even on the heavily developed island of Oahu, in areas of native forest. Overall, Engytatus species seem to be generally overlooked due to their inconspicuous habits and specialized associations with increasingly rare host plants.

\section{Engytatus henryi sp. $\mathrm{n}$.}

http://zoobank.org/4046845E-2F99-4EE4-A86B-041E2FE1303C

Description. Male with general form slender, elongate, parallel-sided (Fig. 1); overall length 3.90-4.10, length from tip of tylus to cuneal fracture 2.60-2.80, maximum width (across base of cuneus) 1.00-1.05. General coloration pale yellowish green, with base of head, anterior margin of pronotum, and entire abdomen bearing more saturated green to bluish-green coloration.

Head length 0.30 , width across eyes 0.52 , pale yellowish green with more saturated bluish-green coloration at posterolateral margins; eyes relatively small, dark reddishblack, length 0.15 , width 0.10 ; vertex width 0.32 , bearing scattered moderately long, semi-erect, pale setae. Antennae long, slender, all segments very pale yellowish, segment I bearing 3 erect, golden, spinose setae, all segments thickly covered with short, semierect pale setae, lengths of segments I-IV $=0.40,1.10,1.15,0.50$. Rostrum length 1.25 , reaching apices of middle coxae, pale golden yellow, extreme tip dark.

Pronotum length 0.60 , width 0.80 , pale yellowish green, bearing scattered semierect pale setae. Scutellum length 0.40 , width 0.35 , pale yellowish-green, bearing scattered semi-erect pale setae.

Hemelytra translucent, uniformly pale yellowish green except extreme posterior apex of cuneus brown (Fig. 1); entire hemelytral surface set with simple, semi-recumbent pale setae; wing membrane very pale grey, veins yellowish green. 


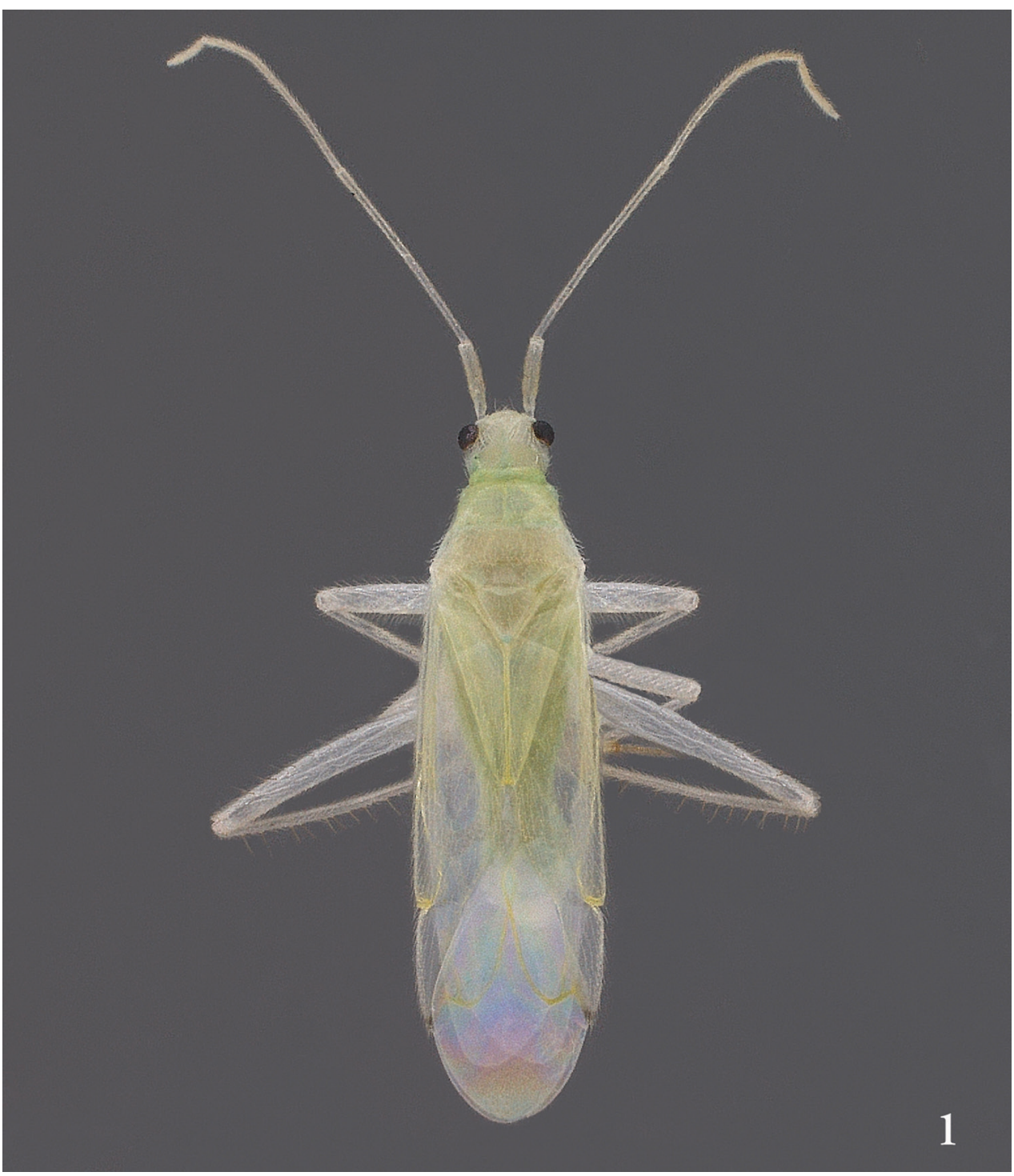

Figure I. Engytatus henryi sp. n., male, dorsal habitus photograph. Specimen from Kaluaa Gulch, Waianae Mountains, Oahu.

Legs slender, elongate (Fig. 1), very pale yellow, tarsi pale golden brown; all leg segments clothed with very short, pale, recumbent setae; anterior margins of all femora bearing -10 evenly spaced, slender, erect, spine-like setae; posterior margin of fore femur with numerous slender, erect, pale setae; posterior margins of middle and hind femora each with 3-4 very long, slender, erect pale setae, lengths of setae subequal to greatest width of corresponding femur on which they occur; anterior margin of hind tibia with scattered long, erect, spine-like setae, lengths of setae $-2 \times$ the tibial width. 


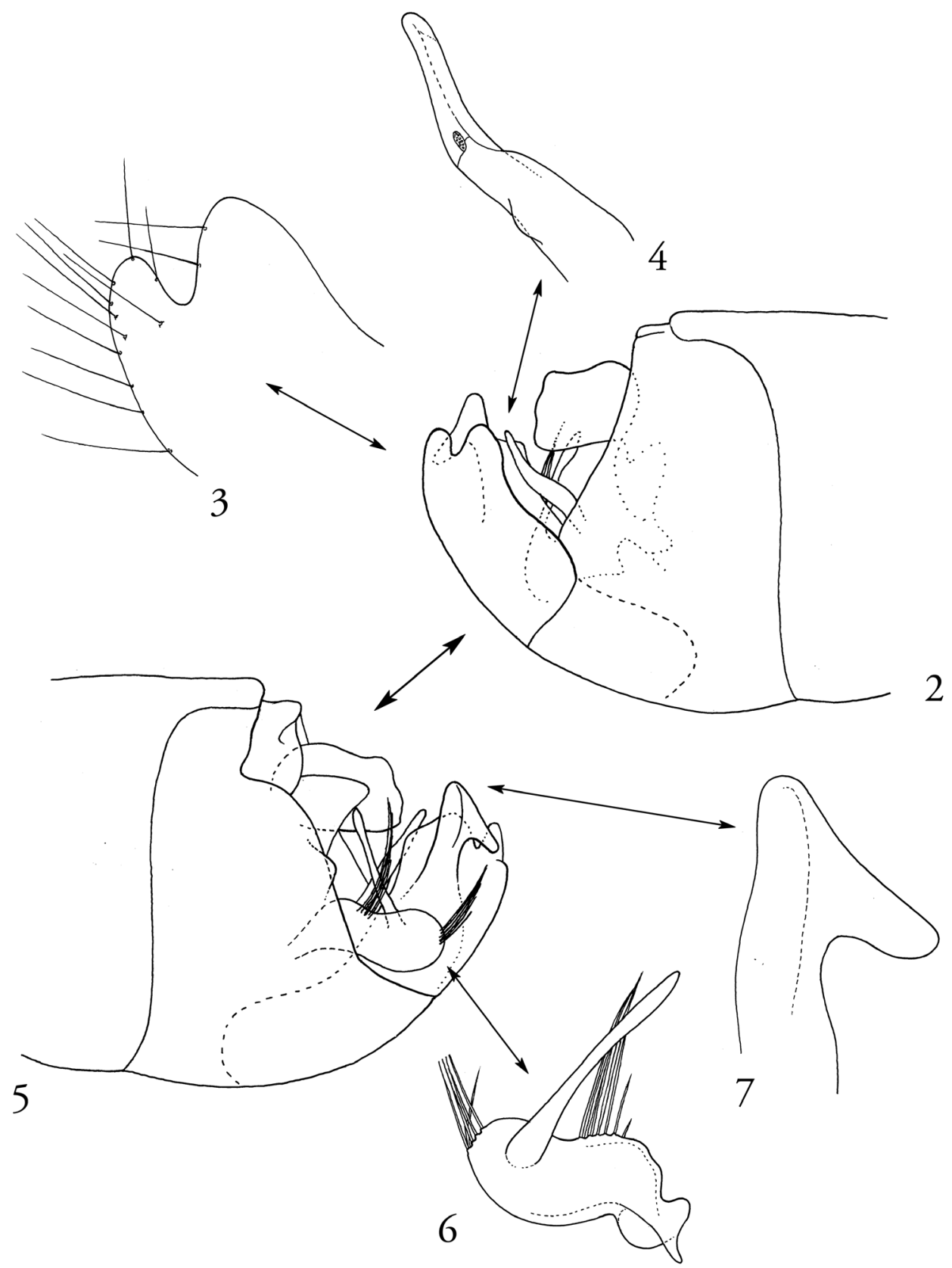

Figures 2-7. Engytatus henryi sp. n., male genitalic structures. Specimen from Kaluaa Gulch, Waianae Mountains, Oahu. 2 Male terminal abdomen, right lateral view 3 Terminal processes on right side of male pygophore, right lateral view 4 Male right paramere, right lateral (outer) view 5 Male terminal abdomen, left lateral view $\mathbf{6}$ Male left paramere, right lateral (inner) view 7 Terminal process on left side of male pygophore, left lateral view. 


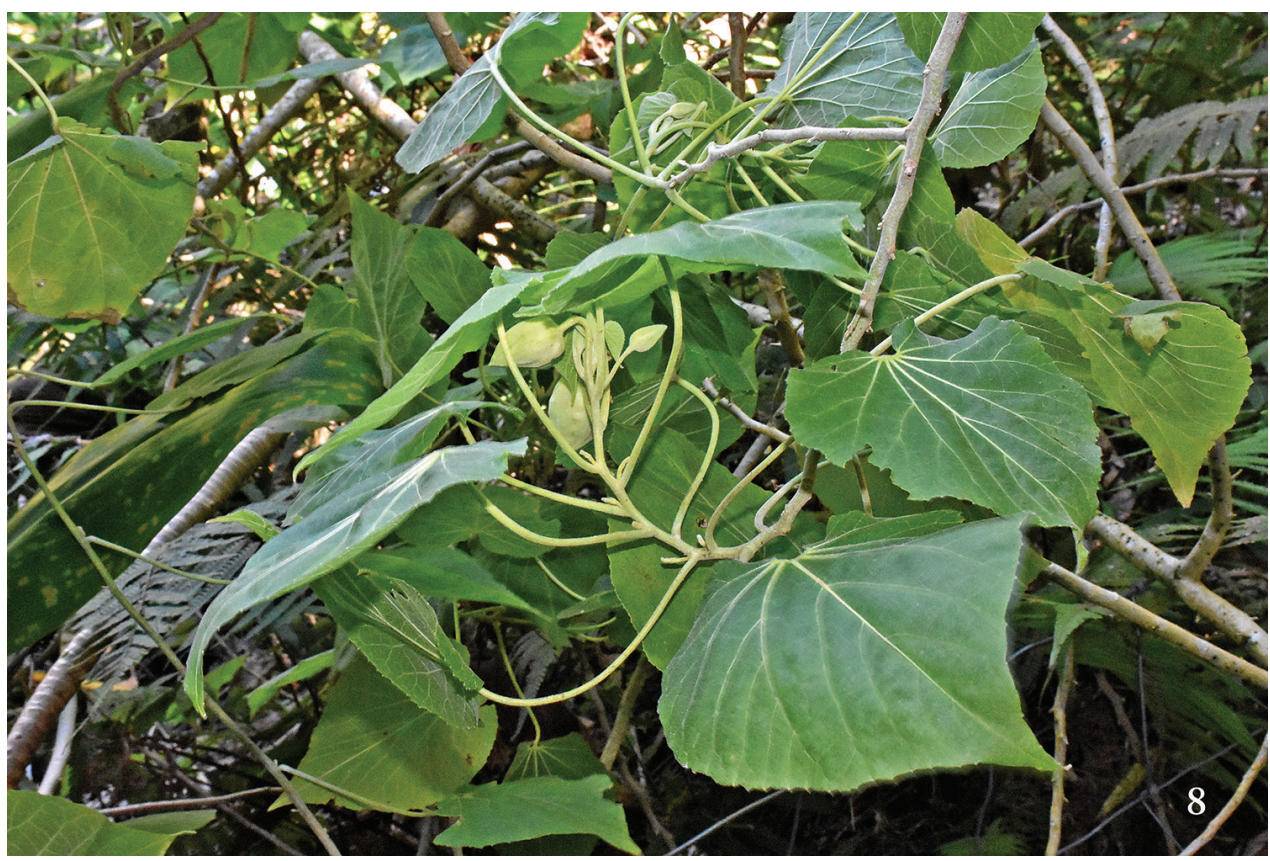

Figure 8. Abutilon sandwicense, host plant for Engytatus henryi sp. n.; photograph taken at type-locality in middle Kaluaa Gulch, Waianae Mountains, Oahu.

Ventral surface predominantly pale green, clothed with short, recumbent pale setae, these setae becoming longer and more numerous adjacent to genital cavity.

Male genitalia with right paramere slender and finger-like (Fig. 4); left paramere stout and bilobate basally, basal lobe bearing acuminate tuft of long, dark setae, distal lobe with slender, elongate, darkly sclerotized process, apex of distal lobe with acuminate tuft of long setae (Fig. 6); proctiger with two small apical lobes on right side when viewed laterally (Figs 2, 3), left side with larger, hook-like process (Figs 5, 7).

Female length overall length 4.20-4.30, length from tip of tylus to cuneal fracture 2.90-3.00, maximum width (across base of cuneus) 1.05-1.10; similar to male in general structure and coloration, but slightly more yellowish.

Host plant. Abutilon sandwicense (O. Degener) Christophersen (Malvaceae).

Types. Holotype, male, HAWAIIAN ISLANDS, Oahu, Waianae Mountains, middle section of Kaluaa Gulch, W. of Schofield Barracks, $1600 \mathrm{ft}$. [485 m.], 21 $27^{\circ} 49^{\prime \prime N}$, $158^{\circ} 06^{\prime} 34^{\prime \prime W}, 26$ April 2017, CL 8527, D. A. Polhemus (BPBM). Paratypes: HAWAIIAN ISLANDS, Oahu: 10 males, 16 females, same data as holotype (BPBM, USNM).

Etymology. The name "henryi" is a patronym honoring Dr. Thomas J. Henry for his many years of scientific effort devoted to the study of Heteroptera, particularly Miridae.

Discussion. Engytatus henryi runs to E. cyrtandrae in the key of Gagné (1968), by virtue of its parallel-sided form, pale dorsal pubescence, elongation of the head behind the eyes, uniformly pale antennae, and pale-colored body and wings with only a small dark mark at the extreme apex of the cuneus (Fig. 1). It differs from E. cyrtandrae in 
its larger size, with the overall length across both sexes being $3.90-4.10 \mathrm{~mm}$, versus 3.13-3.28 $\mathrm{mm}$ in E. cyrtandrae; by having a much different set of structures at the apex of the pygophore, consisting of two small, rounded lobes on the right side (Figs 2, 3) and a large, hooked lobe on the left (Figs 5, 7), rather than a pair of more developed processes on the right side, one acuminate and the other bulb-like, as in E. cyrtandrae (see figs 5a-b in Gagné 1968); and by the shapes of the male parameres (Figs 4, 6).

Ecological notes. The type series of E. henryi was taken from a stand of Abutilon sandwicense (Fig. 8) in a fenced enclosure along the middle reach of Kaluaa Gulch, on the windward side of the Waianae Mountains in western Oahu. Abutilon sandwicense is a sprawling to arborescent, large-leaved shrub that was formerly common in the understory of Hawaiian mesic forests, but has been badly reduced in extent by wildland fire and the depredations of feral pigs, such that it is now listed as Endangered under the federal Endangered Species Act.

\section{Engytatus kabakai (Asquith), comb. n.}

Cyrtopeltis kahakai Asquith, 1993: 17.

Discussion. In his description of C. kahakai, Asquith (1993) did not provide a subgeneric placement within Cyrtopeltis or otherwise discuss his generic assignment. In the assessment of the author, C. kahakai is clearly congeneric with the remainder of the endemic Hawaiian dicyphine radiation, all other members of which were assigned to the genus Engytatus when the latter group was elevated from subgeneric to generic status by Cassis (1986). The current nomenclatural adjustment thus aligns the species binomial with current taxonomy.

\section{Engytatus terminalis (Gagné)}

Cyrtopeltis terminalis Gagné 1968: 42.

Engytatus terminalis: Schuh 1995: 497.

Material examined. HAWAIIAN ISLANDS, Oahu: 2 males, 2 females, Koolau Mountains, Mt. Tantalus area, gulch crossing on Kaluawahine Trail, $1500 \mathrm{ft}$ [455 m], $21^{\circ} 20^{\prime} 13^{\prime \prime N}, 157^{\circ} 48^{\prime} 55^{\prime \prime W}, 23$ May 2017, on Cyrtandra cf. sandwicensis, CL 8528, D. A. Polhemus (BPBM); 3 males, 3 females, Waianae Mountains, Honouliuli Forest Reserve, South Fork of Kaluaa Gulch, 26 April 1970, on Cyrtandra christophersenii [= C. waianaeensis x C. garnotiana], W. C. Gagné (BPBM); 1 male, 1 female, Koolau Mountains, Honolulu Watershed Forest Reserve, Kului Gulch, 400 m, 31 January 1971, on Cyrtandra cordifolia W. C. Gagné (BPBM).

Ecological notes. Three species of Hawaiian Engytatus, all of them endemic to Oahu, appear to be exclusively associated with the host-plant genus Cyrtandra in the 
Gesneriaceae, which contains 58 endemic Hawaiian species, all apparently derived from a single colonizing ancestor (Wagner et al. 1999, Cronk et al. 2005). Previously, Gagné (1968) speculated that specialization on individual species within this diverse local plant radiation could be a significant species isolating mechanism within Hawaiian Engytatus.

In regard to E. terminalis, Gagné (1968) noted its association with Cyrtandra, but did not specify which species was involved. Bishop Museum specimens collected subsequent to his study bear host-plant labels indicating that they were taken on C. cordifolia Gaudichard. More recently, specimens have been taken on the slopes of Mt. Tantalus, in the Koolau Mountains behind Honolulu, from Cyrtandra cf. sandwicensis. The hostplant determination for these latter specimens is provisional because hybrids between C. sandwicensis (H. Léveillé) H. St. John \& Storey and C. grandiflora Gaudichard are known to occur in the Mt. Tantalus area, based on Bishop Museum herbarium specimens, but the large, pubescent leaves of the plants in question are most similar to those of $C$. sandwicensis. It therefore appears that E. terminalis occurs on at least two Cyrtandra species in the Koolau Mountains. Other Gagné specimens in the Bishop Museum from Kaluaa Gulch, in the Waianae Mountains, are recorded as having been taken on $C$. christophersenii H. St. John \& Storey, which is now considered a hybrid of C. waianaeensis H. St. John \& Storey and C. garnotiana Gaudichard (Wagner et al. 1999). Engytatus terminalis thus utilizes a minimum of three species of Cyrtandra across Oahu as a whole, to some extent invalidating the hypothesis of Gagné (1968) that individual host-plant association would prove to be a species isolating mechanism in the genus.

\section{Engytatus confusus (Perkins)}

Cyrtopeltis confusa Perkins, 1911: 729.

Engytatus confusus: Zimmerman 1948: 189.

Cyrtopeltis (Engytatus) confusa: Carvalho 1958: 185.

Material examined. HAWAIIAN ISLANDS, Oahu: 6 males, 9 females, Waianae Mountains, Mt. Palikea, gulch head NE of summit, $915 \mathrm{~m}, 21^{\circ} 24^{\prime} 52^{\prime \prime} \mathrm{N}, 158^{\circ} 05^{\prime} 59^{\prime \prime} \mathrm{W}$, 28 August 2013, on Cyrtandra waianaeensis, CL 8518, D. A. Polhemus (BPBM); 2 females, Waianae Mountains, Mt. Palikea, head of Palawai Gulch, 845 m, 21 $24^{\prime} 46^{\prime \prime} \mathrm{N}$, 158 05'59"W, 28 August 2013, on Cyrtandra waianaeensis, CL 8518, D. A. Polhemus (BPBM); 4 males, 4 females, Koolau Mountains, Punaluu Valley, 1000 ft, 28 September 1968, on Cyrtandra propinqua, W. C. Gagné (BPBM); 2 males, Waianae Mountains, Kawaihapoi Gulch, 548 m, 29 September 1971, on Cyrtandra sp., W. C. Gagné (BPBM).

Ecological notes. The association of this species with the host-plant Cyrtandra cordifolia was previously reported by Gagné (1968). Further specimens have been subsequently collected on $C$. propinqua C. N. Forbes and C. waianaeensis H. St. John \& Storey. Engytatus confusus therefore seems to occur on at least three species of Cyrtandra on Oahu, one of which is also utilized by E. terminalis. This once again indicates that individual host-plant association is not a strong isolating mechanism for the Oahu Engytatus species feeding on Cyrtandra. 


\section{Engytatus hawaiiensis (Kirkaldy)}

Cyrtopeltis hawaiiensis Kirkaldy, 1092: 138.

Engytatus hawaiiensis Zimmerman, 1948: 1988.

Cyrtopeltis (Engytatus) hawaiiensis: China and Carvalho 1952: 160.

Material examined. HAWAIIAN ISLANDS, Maui: 1 male, 1 female, East Maui, Koolau Forest Reserve, 2042 m, 8 August 1973, on Dubautia cf. coriacea [=D. thyrisiflora], W. C. Gagné (BPBM); 6 males, 7 females, Haleakala National Park, West Rim, 9600 ft, 12 August 1975, on Railliardia [= Dubautia sp.], J. W. Beardsley (BPBM).

Ecological notes. This species has been previously recorded as occurring on several species of Railliardia (Gagné 1968), a host-plant genus subsequently synonymized within Dubautia, in the Asteraceae. Based on these records and examination of other Bishop Museum specimens, E. hawaiiensis occurs on Dubautia menziesii (A. Gray) D. D. Keck, D. platyphylla (A. Gray) D. D. Keck, and D. thyrisiflora (Sherff) D. D. Keck, and thus is not strictly confined to a single host-plant species within this genus.

\section{Engytatus sidae (Gagné)}

Cyrtopeltis sidae Gagné, 1968: 40.

Engytatus sidae: Schuh, 1995: 497.

Material examined. HAWAIIAN ISLANDS, Lanai: 15 males, 8 females, Kaumolu Bay heiau, 7 February 1971, on Sida sp., J. W. Beardsley (BPBM).

Ecological notes. This species was originally described from Maui, and the record above demonstrates its occurrence on Lanai as well.

\section{Acknowledgments}

The author wishes to thank Karl Magnacca, Vincent Costello, and Joby Rohrer for their kind assistance in providing access to protected areas in the Waianae Mountains of Oahu under the oversight of the U. S. Army. In addition, the author thanks Neal Evenhuis and Jim Boone of the Bishop Museum for continued logistical and imaging systems support of research relating to the taxonomy and biogeography of Hawaiian Heteroptera.

This paper represents contribution 2017-005 to the Hawaii Biological Survey.

\section{References}

Asquith A (1992) A New Species of Cyrtopeltis from coastal vegetation in the Hawaiian Islands (Heteroptera: Miridae: Dicyphinae). Pacific Science 47(1): 17-20. https://scholarspace. manoa.hawaii.edu/bitstream/10125/1743/1/v47n1-17-20.pdf 
Carvalho JCM, Usinger RL (1960) New species of Cyrtopeltis from the Hawaiian Islands with a revised key (Hemiptera: Miridae). Proceedings of the Hawaiian Entomological Society 17: 249-254. https://scholarspace.manoa.hawaii.edu/bitstream/10125/10815/1/17_249-254.pdf Cassis G (1986) A systematic study of the subfamily Dicyphinae (Heteroptera: Miridae). PhD Thesis, Oregon State University, Corvallis. University Microfilms International, Ann Arbor 1986, 390 pp.

Cronk QCB, Kiehn M, Wagner WL, Smith JF (2005) Evolution of Cyrtandra (Geesneriaceae) in the Pacific Ocean: the origin of a supertramp clade. American Journal of Botany 92(6): 1017-1024. https://doi.org/10.3732/ajb.92.6.1017

Gagné WC (1968) New species and a revised key to the Hawaiian Cyrtopeltis Fieb. with notes on Cyrtopeltis (Engytatus) hawaiiensis Kirkaldy (Heteroptera: Miridae). Proceedings of the Hawaiian Entomological Society 20(1): 35-44. https://scholarspace.manoa.hawaii.edu/ bitstream/10125/10948/1/20_35-44.pdf

Perkins RCL (1912) Notes on Hawaiian Heteroptera with descriptions of new species. Transactions of the Entomological Society of London for 1911, Part IV: 728-737.

Schuh RT (1995) Plant Bugs of the World (Insecta: Heteroptera: Miridae): systematic catalog, distributions, host list and bibliography. New York Entomological Society, New York, 1329 pp.

Tanada Y, Holdaway FG (1954) Feeding habits of the tomato bug, Cyrtopeltis (Engytatus) modestus (Distant), with special reference to the feeding lesion on tomato. University of Hawaii, Hawaii Agricultural Experiment Station, Technical Bulletin 24: 1-40. https://core.ac.uk/ download/pdf/32298032.pdf

Wagner WL, Herbst DR, Sohmer SH (1999) Manual of the Flowering Plants of Hawai'i (revised edition, 2 volumes). University of Hawaii Press, Honolulu.

Zimmerman EC (1948) Insects of Hawaii (Vol. 3) - Heteroptera. University of Hawaii Press, Honolulu, 255 pp.

\section{Appendix I}

Checklist of Hawaiian Engytatus species with known host plants and distributions within the Hawaiian Islands.

\begin{tabular}{lll}
\hline \multicolumn{1}{c}{ Species } & \multicolumn{1}{c}{ Host plant(s) } & Distribution \\
\hline Engytatus confusus (Perkins) & $\begin{array}{l}\text { Cyrtandra waianaeensis (Gesneriaceae) } \\
\text { Cyrtandra propinqua (Gesneriaceae) }\end{array}$ & Oahu \\
\hline Engytatus cyrtandrae (Gagné) & Cyrtandra sp. (Gesneriaceae) & Oahu \\
\hline Engytatus hawaiiensis (Kirkaldy) & $\begin{array}{l}\text { Dubautia menziesii (Asteraceae) } \\
\text { Dubautia platyphylla (Asteraceae) } \\
\text { Dubautia thyrisiflora (Asteraceae) }\end{array}$ & Maui \\
\hline Engytatus henryi sp. $\mathrm{n}$. & Abutilon sandwicense (Malvaceae) & Oahu \\
\hline Engytatus kahakai (Asquith) & Scaevola sericea (Goodeniaceae) & Kauai, Molokai \\
\hline Engytatus lysimachiae (Carvalho \& Usinger) & Lysimachia sp. (Primulaceae) & Kauai \\
\hline Engytatus perplexa (Gagné) & Dubautia sp. (Asteraceae) & Maui \\
\hline Engytatus phyllostegiae (Carvalho \& Usinger) & Phyllostegia sp. (Labiatae) & Oahu \\
\hline & $\begin{array}{l}\text { Cyrtandra } \text { cf. sandwicensis (Gesneriaceae) } \\
\text { Engytatus terminalis (Gagné) }\end{array}$ & Oahu \\
& $\begin{array}{l}\text { Cyrtandra cordifolia (Gesneriaceae) } \\
\text { Engrtandra christophersenii (Gesneriaceae) }\end{array}$ & \\
\hline
\end{tabular}

